\title{
Akademisk fagskriving på ingeniørstudiet
}

\author{
Peer reviewed article
}

Gunvor Sofia Almlie*

Universitetet i Agder

\begin{abstract}
In the Norwegian engineering education, there has been an increasing focus on writing instruction in the last decade. Although writing in the disciplines seems to be the overall goal, the disciplines themselves are not prepared for nor equipped to provide the writing instruction the students need.

This article attempts to measure the effect of a writing course that was given in the first semester of the engineering study at the University of Agder in 2018. The writing course was a collaboration between the disciplines of engineering, the university library and a writing instructor with permanent affiliation to the Department of Engineering. The aim of the collaboration was to gather the expertise from the disciplines and the university library in the design of writing courses in engineering. The survey seeks to find answers to the students' experience of the writing course, and the challenges they face in academic disciplinary writing. Answers from the students are compared with answers from conversations with study coordinators and subject teachers in the five engineering study programs at UiA.

The results show that the students find teaching and supervision useful, both to achieve the learning outcomes for the course, but also for use in other writing situations in their education. The problems students have with academic writing are both discipline-specific and general. They experience challenges in three areas in particular: genre orientation, text structure and information literacy.

The close collaboration between the writing instructor, the library and the engineers is bridge-building and contributes to a holistic writing instruction in the engineering education. The interdisciplinary collaboration also raises the competence of all staff involved.
\end{abstract}

Keywords: akademisk skriving, ingeniørutdanning, fagdisiplin, sosiokulturell skriveundervisning, rettleiing, skrivemiljø, skrivestøtte

\section{*Contact}

email: gunvor.s.almlie@uia.no

Nordic Journal of Information Literacy in Higher Education, 2020. C2020 Gunvor Sofia Almlie

This is an Open Access article distributed under the terms of the Creative Commons Attribution Noncommercial 4.0 Unported License (http://creativecommons.org/licenses/by-nc/4.0/) 


\section{Innleiing}

Ved ingeniørstudia i Noreg blir det forventa at studenten skal kunne skrive når ho byrjar på studiet. Sjølv om utdanninga har mange innslag av praktisk arbeid, er det oftast det skriftlege arbeidet studenten blir evaluert gjennom. Gode skriveferdigheiter er derfor viktig for å få ei god bacheloroppgåve.

Skriving i profesjonsstudia generelt, og ingeniørstudia spesielt, har fått meir fokus dei siste tiåra. Drivkrafta og formålet med å fokusere på akademisk skriving på ingeniørstudiet kjem delvis frå næringslivet (framtidige arbeidsgjevarar) og delvis frå universitetet. Kravet om skriveferdigheiter er også nedfelt i Rammeplanen for ingeniørutdanninga i Noreg. Universitets - og høyskolerådet (UHR) krev at den norske ingeniørutdanninga har eit sterkare fokus på språk og formidling. Dette kjem fram i rammeplanane dei siste ti åra (Lovdata, 2018; Universitetsog høyskolerådet, 2011).

Samtidig med eit sterkare fokus på akademisk skriving på universiteta generelt, har det også kome fleire skrivesenter ved norske universitet og høgskular i løpet av dei siste tiåra (Andersen, Fagerlid, Larsen, \& Straume, 2017, s.102). Skrivetilbodet på universitetsbiblioteka har også auka, og dei ulike ingeniørstudia i landet vårt løyser ofte krava om skriveferdigheiter ved å invitere universitetsbiblioteket til å halde skrivekurs. Kursa kan variere i stor grad frå svært generelle skrivekurs til skrivekurs som er meir tilpassa ingeniørutdanninga (innhenta svar frå Universitetsbiblioteket ved UiA, Universitetsbiblioteket ved OsloMet, Studieverkstedet v/OsloMet, Universitetsbiblioteket ved USN og skriveinstruktør ved bachelor i kjemi ved NTNU. Trass fokus på skriving har ikkje skriveundervisninga eller skrivepraksis endra seg i særleg grad ved den norske ingeniørutdanninga.

Ofte ser ein at det generelle skrivetilbodet frå skrivesentra og biblioteka ikkje når så godt fram til ingeniørstudentane. Ein grunn til dette kan vere at det blir oppfatta som for generelt, og dermed ikkje tilpassa spesifikke målgrupper (Hårklau, Vik-Haugen \& Våga, 2017). Kurshaldarane ved universitetsbiblioteket ved UiA bekrefter at det er relativt få ingeniørstudentar som møter til dei generelle kursa som blir tilbodne. Likevel etterlyser fagmiljøa meir fokus på fagskriving. Det kan verke som om det har oppstått eit tomrom mellom fagmiljøa og deira syn på kva slags skriveopplæring som trengs for ingeniørstudentane og dei generelle skrivetilboda ved universiteta.

Det er i landskapet mellom skriveundervisning i fagmiljøa og skrivetilbod i skrivemiljøa (skrivesenter, veilednigstilbod ved biblioteka og generelle skrivekurs) eg befinn meg. I dette landskapet ser ein eit forsterka fokus på, og interesse for, akademisk skriving på ingeniørstudia. Ein ser også ei opptrapping i kompetanseheving og kurstilbod frå skrivemiljøa. Spørsmålet er om tilboda til sistnemnde greier å lokke ingeniørstudentane til seg eller om ingeniørutdanninga må påleggast ei grundigare skriveopplæring som eit fast innslag i bachelorgraden, noko som allereie blir gjort ved nokre av universiteta og høgskulane i Noreg.

\section{Bakgrunn}

Ved overgangen frå vidaregåande skule til universitet kjem og overgangen til fagskriving. Fagskriving inneber både sjangermeistring og meistring av skrivemåtar som er forventa $\mathrm{i}$ 
fagdisiplinen. Den såkalla fagskrivinga eller også sjangerorienterte skrivinga har vore ei etablert tilnærming til skriveopplæring dei siste tiåra både nasjonalt (Dysthe, Hertzberg \& Hoel, 2010; Eik-Nes, 2007; Folkvord \& Thowsen, 2007; Hertzberg \& Roe, 2016; Jonsmoen \& Greek, 2012; Smidt, 2010; Strand, 2007) og internasjonalt (Bazerman, Little, Bethel, Chavkin, Fouquette \& Garufis, 2005; Hyland, 2002a; Hyland, 2002b; Hyland, 2007; Peterson, 2012; Zhu, 2004).

Internasjonalt, og spesielt i USA, er det gjort mykje forsking under overskrifta Writing in the disciplines (WID). Denne tilnærminga til skriveopplæring vektlegg ikkje generell skriveundervisning, men skriveundervisning i fagspesifikke sjangrar, format og konvensjonar. (Bazerman et al., 2005).

I norsk skule har skriving i alle fag vore i fokus sidan det kom med i Kunnskapsløftet i 2006 (Utdannings- og forskningsdepartementet, 2006). Likevel ser ein at overgangen frå vidaregåande skule til universitet er ein overgang til ei ny type skriving også i norsk samanheng. Fagskriving er i så måte ei relativt ukjent oppgåve for ingeniørstudenten i fyrste studieår (Berge, Evensen, Vagle \& Hertzberg, 2005; Dysthe et al., 2010; Evensen \& Hoel, 1997; Jonsmoen \& Greek, 2012).

Diskursen om skriveundervisning på ingeniørstudia, nasjonalt og internasjonalt dreier seg blant anna om kvar skriveopplæringa bør ligge og kven som skal ha ansvar for den: fagmiljøa, skrivemiljøa eller begge (Peterson, 2012).

I fagmiljøa innan ingeniørfag internasjonalt ser ein tydelege haldningar om at studentane bør lære seg å skrive innanfor dei gitte rammene fagmiljøa har (Gassman, Maher \& Timmerman, 2013; Howard, Khosronejad \& Calvo, 2017; Jordan \& Kerdowicz, 2011; Zhu, 2004). Eit argument er at sosialiseringa inn i eit fagområde (ein disiplin) sjåast som så viktig i fagmiljøa at skriveundervisninga er ønska tillagt fagfeltet heller enn til dei generelle skrivetilboda ved universiteta (Zhu, 2004). Skriving blir sett på som viktig i fagmiljøa, men det faglege og dei faglege konvensjonane er viktigare enn sjølve språkføringa (Howard et al., 2017).

Samtidig viser forskinga at fagfeltet ikkje alltid greier å møte dei språklege utfordringane som studentane har (Howard et al., 2017; Jonsmoen \& Greek, 2012; Jordan, 2011; Zhu, 2004). Ofte kan fagmiljøa uttrykke motvilje mot å fokusere på språk og skriving når dei rettleier, sjølv om dei innser at behovet er der, fordi dei sjølve manglar kompetanse (Howard et al., 2017). Manglande fokus og kompetanse innad i fagmiljøa blir også skildra i dei norske profesjonsutdanningane (Jonsmoen \& Greek, 2012), der det blir hevda at tilbakemeldingar frå fagmiljøet ofte ikkje fører til læring. Dette kan tyde på at fagmiljøet ikkje kjenner godt nok til studentane sine utfordringar i skrivearbeidet, og kanskje sjølve manglar tekstmedvit. Ein greier å gjenkjenne ein tekst som dårleg, men kan ha større problem med å hjelpe studenten til forbetring (Howard et al., 2017; Jonsmoen \& Greek, 2012; Kim \& Olson, 2020).

Fagmiljøa ønsker å ha ei sentral rolle i skriveopplæringa, men dei prioriterer det fagspesifikke innhaldet over det språklege i vurderingssituasjonar (Jordan \& Kedrovicz, 2011). Dei ingeniørretta fagmiljøa lagar på den måten eit uheldig skilje mellom språk og fag.

Bernadier (2019) meiner at dei retoriske grepa får for liten plass i den sjangerorienterte undervisninga. Malar og faste strukturar står ofte i vegen for tekstflyt og argumentasjonsflyt. Jonsmoen og Greek (2012) nemner også at studentane finn det vanskeleg å skrive etter formelle krav, og at fagmiljøa verkar meir opptekne av at studentane skal innfri desse krava enn å skrive godt. 
Det kan sjå ut som om dei vitskapeleg tilsette på ingeniørstudiet ser på seg sjølve som tilretteleggarar for skriving i form av oppgåvegjeving og prosjekt. Tilbakemeldingane dei gir er fagspesifikke, og sjeldan språklege (Jonsmoen \& Greek, 2012; Zhu, 2004). I så måte blir skrivopplæringa i fagmiljøa ei 'skrive for å lære'-tilnærming (Dysthe, 2010) i staden for ei bevisstgjering på sjølve skriveprosessen der studentar kan få utvikle god språkføring og retoriske ferdigheiter (Zhu, 2004).

Denne todelinga av skrivetilnærming er uheldig i skriveopplæringa. Ved skriving av fagteksten heng fagforståing, sjangerforståing og språkforståing så tett saman at dei kanskje ikkje bør splittast (Jordan \& Kedrowicz, 2011). Derfor er det svært nyttig for den skrivande ingeniørstudenten å få ei god breidde i skriveundervisninga det fyrste året. Tett samarbeid mellom skrivemiljøa og fagmiljøa kan bidra til den breidden.

\section{Problem}

Gode skriveferdigheiter, både generiske og fagpesifikke, er viktig for ingeniørstudentane. Vi ser likevel at sjølv med auka fokus på akademisk skriving på ingeniørutdanninga i Noreg, kjem det ikkje tydeleg fram kva innhaldet i skriveopplæringa skal vere. Det er også uklart kven som skal stå for skriveopplæringa. Det er opp til kvar enkelt institusjon å tilby skrivekurs, og kursa kan ha varierende innhald (Våga, Hårklau \& Vik-Haugen, 2017) og varierande effekt.

Skrivemiljøa har ofte ei generisk tilnærming til skriving, skriveprosess og kjeldekompetanse, men kan mangle innsyn i det fagspesifikke. Fagmiljøa er ofte opptekne av det fagspesifikke (Jonsmoen \& Greek, 2012; Zhu, 2004), men dei innser at dei kjem til kort når det gjeld skriveopplæring og rettleiing i språk, retorikk og informasjonskompetanse.

Ved UiA er skriveundervisninga på ingeniørstudiet eit tett samarbeid mellom bibliotek, skrivelærar i fagmiljøet og sjølve fagmiljøet. Både skrivemiljø og fagmiljø jobbar dermed saman for ei spissa skriveopplæring på ingeniørstudiet. I tillegg til skrivekurset i oppstartsemesteret følger skrivelærar studentane vidare i studieforløpet og bidrar i rettleiing og skrivekurs i bacheloroppgaven og masteroppgaven.

I denne artikkelen er det forsøkt å måle studentane si oppleving av eit slikt kurs. Det er stemma til ingeniørstudenten som skal kome fram her. Sjølv om denne stemma åleine ikkje kan eller bør stå for kvalitetssikring av skriveundervisninga, er den eit viktig bidrag. Som eit tillegg til studenten si stemme, er studieprogramleiarar ved dei fem ulike studieretningane på ingeniørstudiet intervjua.

\section{Forskningsspørsmål}

a) Korleis opplever ingeniørstudentane i 1 . semester skrivekurs og kva er vanskeleg med fagskriving?

b) Korleis kan vi lage nyttige skrivekurs på ingeniørutdanninga?

Hovudformålet med denne undersøkinga er å finne måtar å lage gode og tilpassa skrivekurs til ingeniørstudentar på. Studentane si evaluering av eit samarbeidskurs mellom 
fagmiljø og skrivemiljø er utgangspunktet for dette. Eit anna formål er å bidra i diskursen om skriving på ingeniørstudiet i Noreg.

\section{Kontekst}

Denne undersøkinga er eit samarbeid mellom bachelorprogram ved tre ulike fakultet ved Universitetet i Agder og Universitetsbiblioteket. Dei tre fakulteta er Fakultet for humaniora og pedagogikk, Handelshøyskolen ved UiA og Fakultet for teknologi og realfag. Spørjeundersøkinga var utforma av undervisarar frå alle tre fakultet. Denne artikkelen er kun basert på funna frå bachelorprogramma for ingeniørutdanningane ved Fakultet for teknologi og realfag.

\section{Metode}

Ei kvalitativ spørjeundersøking av studentane si oppleving av skrivekurs i fyrste semester på bachelorstudiet vart utført. Spørjeundersøkinga var basert på ei liknande undersøking frå to australske universitet; Monash og Deakin (Feedback for Learning at Monash University and Deakin University, Dawson, Henderson, Mahoney, Phillips, Ryan, Boud \& Molloy, 2018). Den originale spørjeundersøkinga hadde 80 variablar. 12 av desse blei brukt $i$ vår undersøking ved UiA. Undersøkinga blei utført i november 2018 og formidla til alle studentane på emnet Ingeniørfagleg innføringsemne (TFL115) på læringsplattforma Canvas. Av totalt 316 studentar var det 130 som svara på deler av undersøkinga medan 83 fullførte heile. Maksimum responsrate var $41 \%$ og minimum responrate var $26 \%$. 56\% av respondentane har vidaregåande skule som fagleg bakgrunn. Resterande $44 \%$ har fagskule, forkurs for ingeniørutdanning eller liknande.

I tillegg er opne kommentarar frå studentane som svarte på emnet si sluttevaluering også brukt. I sluttevalueringa var responsraten $27 \%$. Sluttevalueringa var digital i Canvas og blei gjennomført november 2018.

Det har også blitt gjort halvstrukturerte dybdeintervju ('skrivesamtalar') med studieprogramleiarar og rettleiarar innanfor fagdisiplinane ved Fakultet for teknologi og realfag, UiA. Innhaldet i skrivesamtalene er brukt for å sjå om det er samsvar mellom det som studentane meiner er utfordrande i skrivearbeidet og det som dei vitskapeleg tilsette på ingeniørstudiet meiner studentane treng opplæring i.

\section{Kursbeskriving}

Kurset i akademisk skriving foregår i fyrste semester av bachelorutdanninga. Skrivekurset er inkludert i eit emne som også inneheld tema som kjemi, miljø og bærekraft, teknologihistorie og studiestrategi (Ingeniørfaglig innføringsemne 7,5 studiepoeng).

Det haldast tre dobbelforelesningar i akademisk skriving ved byrjinga av semesteret etterfulgt av ein periode der studentane jobber gruppevis med ei prosjektoppgåve. Vitskapeleg tilsette på ingeniørstudiet (faglærarar), skriveinstruktør og fagleg tilsett ved universitetsbiblioteket gjev rettleiing kvar veke. Prosjektrapporten skrivast på engelsk. 
Forelesningane i kjemi, miljø og bærekraft, teknologihistorie og studiestrategi blir haldne av vitskapeleg tilsette på ingeniørfag. Skriveforelesningane vert haldne av fast tilsett 'skriveinstruktør' (filolog) ved fakultetet. I tillegg held universitetsbiblioteket, med fagtilsett, forelesningar om kjeldekompetanse. Under rettleiinga av prosjektoppgåva rettleier ingeniørvitskapeleg tilsette, skrivelærar og bibliotekstilsett saman i same rom. Det blir også sett opp ei ekstra rettleiingsøkt i veka med bibliotektilsett og skriveinstruktør i universitetsbiblioteket sine lokaler.

Alle undervisarar og rettleiarar er godt kjende med prosjektoppgåva som studentane arbeider med.

Dei tre dobbelforelesningane i akademisk skriving har tre fokusområder:

1. Sjangerorientering: Prosjektoppgåva skal skrivast som ein ingeniørfagleg rapport.

2.Informasjonskompetanse: Kjeldebruk, kjeldesøk og kjeldekritikk. Denne forelesninga blir halden av universitetsbiblioteket i samarbeid med skriveinstruktør.

3. Skrivekonvensjonar og skriveprosess på ingeniørstudiet: Denne forelesninga handlar både om språk og skriveprosessen, men også om kva type språk som er forventa av studentane på ingeniørstudiet. Dømer kan vere bruk av passivsetningar, formalitet i språket ol. Denne forelesninga er på engelsk og tek føre seg engelsk språk. Modelltekstar blir brukt i undervisninga.

Innhaldet i kurset prøver å dekke dei behova for skriveundervisning som er ytra i fagmiljøa. Kurset er såleis ein introduksjon til den form for skriving som er forventa vidare i ingeniørstudiet; ikkje berre den gitte prosjektoppgåva. Skriveinstruktør, som også er kursansvarleg, følger studentane vidare i skrivearbeidet, spesielt når bachelor $-\mathrm{og}$ masteropgåvene skal skrivast.

Rollene til dei som er involverte i emnet er:

Skriveinstruktør: Skriveinstruktør er kursansvarleg og fast tilsett på Institutt for ingeniørvitskap ved UiA. Fagleg bakgrunn er språkvitskap og samfunnsvitskap. Skriveinstruktør er også forfattar av denne artikkelen.

Vitskapeleg tilsette på ingeniørfag: Det er to fagleg tilsette ingeniørar som er med i både undervisning og vegleiinga i kurset.

Universitetsbiblioteket sin fagansvarleg for ingeniørfag: Biblioteket si viktigaste rolle i dette samarbeidet er vegleiing og undervisning i informasjonsøk, kjeldekritikk og referering, samtidig er også bibliotektilsett godt kjend med oppgåva og krava som stillast til form og innhald. Noverande fagansvarleg på universitetsbiblioteket er også utdanna ingeniør.

Samarbeidet om rettleiinga fungerer slik at tre eller fire rettleiarar er i same rom og rettleier den same studentgruppa side om side. Såleis har rettleiiarane ei aktiv rolle i studentane sin skriveprosess. Rettleiinga er eit tett samarbeid mellom fagmiljø (ingeniør) og skrivemiljø 
(skriveinstruktør og universitetsbiblioteket), og målet er å rettleie både i fagspesifisitet (Hyland, 2002b) og meir generelle skriveaktivitetar som retorikk, argumentasjon og kjeldekompetanse. Når to fagmiljø (skrivemiljø og ingeniørfagleg miljø) rettleier side om side bidrar dette også til at miljøa lærer av kvarandre, og kan få eit meir heilskapeleg syn på skriveopplæringa. Rettleiingsøktene kan difor ofte verke som ein trevegsdialog mellom studentar og dei to fagmiljøa (Pitt, 2016). Rettleiinga av prosjektrapport foregår ein til to økter i veka i sju veker.

\section{Resultat og diskusjon}

Data er delt inn i fire kategoriar:

1. Studentane si oppleving av forelesningane i akademisk skriving

2. Studentane si oppleving av rettleiinga av prosjektoppgåva

3. Studentane sine utfordringar i skriveprosessen

4. Ei samla syntese av kva studiekoordinatorane (ingeniørfagleg tilsette) meiner er viktig i skriveundervisninga

\section{Kategori 1}

Funn frå kategori 1 gir svar på om forelesningar i akademisk skriving opplevast som nyttige. Figur 1 viser at $78 \%$ av respondentane meiner at forelesningar i akademisk skriving er nyttige for å fullføre prosjektoppgåva. 29\% var svært nøgde og 59\% var nøgde.

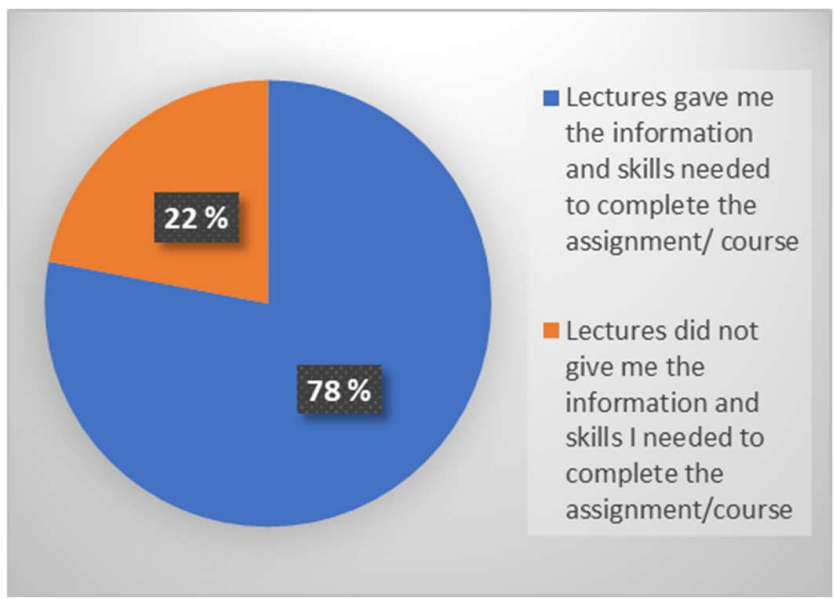

Fig. 1. Studentane si oppleving av forelesningar i akademisk skriving

Forelesningane i akademisk skriving har hovudsakleg vore sjangerorienterte og oppgåveorienterte. Erfaringsmessig er det 'nytteverdien' studentar ofte evaluerer undervisning etter. Når undervisninga er retta inn mot ei spesiell prosjektoppgåve kan det vere lettare for studentane å sjå nytten av den. Samtidig viser dei opne kommentarane fleire nyansar i svara:

Respondent 1: The course taught what to write but not how.

Respondent 2: Følte ikke det ble gitt nok informasjon om hvordan det er forventet man skal skrive. 
Resultatet viser at studentane finn forelesningane nyttige, men det kjem også fram at trening $\mathrm{i}$ retoriske ferdigheiter kan få meir plass i skriveundervisninga.

\section{Kategori 2}

Funna i kategori 2 måler studentane si oppleving av rettleiing og tilbakemelding. $41 \%$ svarer at dei er veldig nøgde med rettleiinga og 56\% er noko nøgd med den. $83 \%$ svarer at dei vil bruke kommentarane frå rettleiar til å forbedre teksten i prosjektoppgåva si.

\begin{tabular}{|l|l|l|l|l|l|l|}
\hline & Never & Rarely & Occasionally & Frequently & Always & $\begin{array}{l}\text { Not able } \\
\text { to judge }\end{array}$ \\
\hline $\begin{array}{l}\text { I use the feedback to } \\
\text { improve future } \\
\text { performance }\end{array}$ & $5 \%$ & $4 \%$ & $18 \%$ & $46 \%$ & $28 \%$ & $5 \%$ \\
\hline $\begin{array}{l}\text { The feedback } \\
\text { motivates in my } \\
\text { studies }\end{array}$ & $1 \%$ & $7 \%$ & $22 \%$ & $42 \%$ & $22 \%$ & $6 \%$ \\
\hline $\begin{array}{l}\text { I discuss feedback } \\
\text { with teacher who } \\
\text { provided it }\end{array}$ & $11 \%$ & $24 \%$ & $27 \%$ & $28 \%$ & $5 \%$ & $6 \%$ \\
\hline
\end{tabular}

Fig. 2. Studentane sin opplevde nyttebruk av rettleiing.

Eit funn som er spesielt interessant $i$ denne kategorien er at $74 \%$ av respondentane meiner at dei vil bruke kommentarar i rettleiinga til å forbedre skrivearbeidet generelt - ikkje berre for den gitte oppgåva (jmf. Fig. 2). Kva betyr det?

Skrivekurset er som tidlegare nemnt, eit introduksjonskurs til ingeniørutdanninga. Det foregår i fyrste semester, og skriveoppgåva studentane har er blant dei fyrste store skriveoppgåvene dei får som ingeniørstudentar. Det dei trener på her vil dei få bruk for når dei skal skrive fagspesifikke tekstar vidare i studiet. Det krev at skriveinstruktør og biblioteket sin fagperson er kjent med kva som forventast av studentane i fagmiljøa.

Undersøkinga viser altså at studentane bruker rettleiinga til å forbedre den aktuelle teksten, men også til skriving generelt. Når tilbakemelding ikkje berre blir brukt til å oppnå læremåla for det gitte arbeidet, men også for vidare skrivearbeid, blir det viktig at rettleiar kan ta ei allsidig rolle. Rettleiinga blir derfor eit samskapingsprosjekt mellom fire partar; faglærar, skrivelærar, bibliotek og studenten sjølv. Å kun ta rolla som fasilitator for skriving (Zhu, 2004) vil derfor ikkje vere tilstrekkeleg. Rettleiar må og vere førebudd på å diskutere fag, språk og kjeldehandsaming med studentane. Dette krev at den enkelte rettleiar må fråskrive seg noko av sin 'monofaglegheit' (Rienecker, Wichmann-Hansen \& Jørgensen, 2019, s. 223) og heller sjå sitt eige fag som ein del av ein heilskap. 


\section{Feedback from supervisor/assessor}
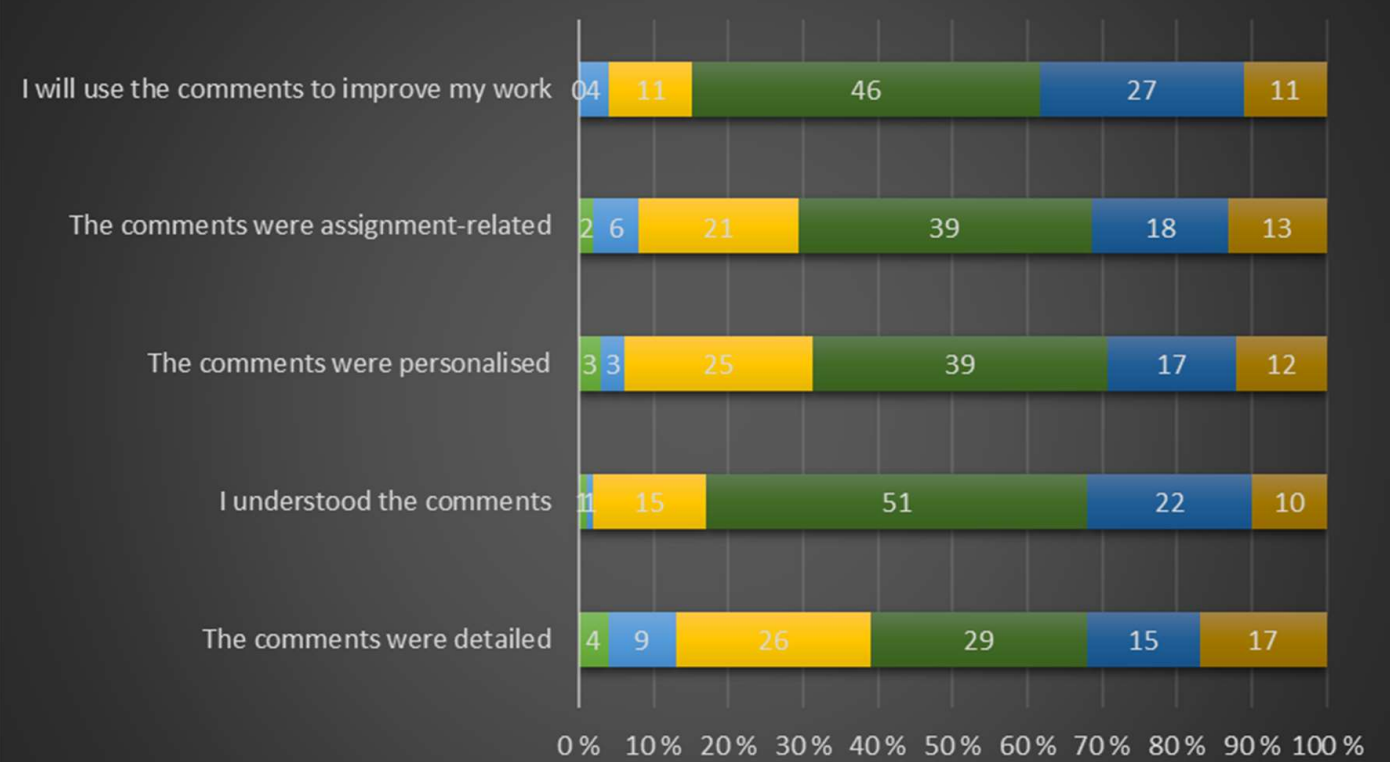

- Strongly disagree

n Disagree

- Neither disagree nor agree

anree

Strongly agree

$\square$ Not able to judge

Fig. 3. Figuren viser korleis studentar oppfattar rettleiing og tilbakemelding på skriftleg arbeid.

Når studentane blir spurt om korleis dei ønsker tilbakemeldingar er det overraskande $35 \%$ som svarer at dei føretrekker elektroniske tilbakemeldingar. I denne rettleiingssituasjonen inneber det kommentarar gitt på skriftleg arbeid via læringsplattforma Canvas eller på epost. $26 \%$ svara at rettleiing ansikt til ansikt er å foretrekke.

I dette kurset har studentane moglegheit til fysiske samtaler og rettleiing kvar veke. Studentane skriv saman i grupper, og rettleiinga foregår med både skriverettleiing og ingeniørfagleg rettleiing. Skrivinga blir såleis ei sosial handling i tråd med sosiokulturell skriveteori, der «kunnskap blir konstruert gjennom samhandling og i ein kontekst» (Dysthe, 2001, s. 42). Samtidig gir rettleiingssituasjonen ei god moglegheit for studentane til å 'sosialiserast' inn i sin fagdisiplin. Denne sosialiseringa skapast blant anna gjennom 'dialog' (Dysthe, 1997) mellom studentane og rettleiarane. Med omgrepet 'dialog' meinast her at samtalen som går føre seg i rettleiingssituasjonen fører til ny kunnskap for alle involverte partar fordi alle tilfører dialogen noko nytt frå sine forståingsunivers. Her er teksten utgangspunkt for dialogen, men også ein del av den. Til dømes kan språklege normer, som i fagmiljøa kan ha vore underkommunisert, bli tydeleggjort av ein meir språkmedviten skrivelærar. Samspelet mellom dei ulike 'stemmene' i rettleiingssituasjonen vil skape ei felles forståing av fag og korleis faget skal kommuniserast. Når rettleiinga er ein dialog mellom skrivemiljø, ingeniørfagleg miljø og ei studentgruppe (og teksten deira) får alle stemmene plass og i fellesskap skapast ei forståing for kva ein god fagtekst er, både språkleg, retorisk, fagleg og formelt (Rienecker et al., 2019). 
Desse aspekta ved rettleiing og tilbakemelding kan lett forsvinne når tilbakemeldingane kun foregår utanom den fysiske samtalen, altså som skriftlege kommentarar på innlevert arbeid, slik $35 \%$ av studentane uttrykkjer at dei ønsker. At kun $26 \%$ av respondentane svara at dei ønsker rettleiing ansikt til ansikt er difor noko skuffande.

\section{Kategori 3}

Den tredje kategorien med data har forsøkt å gi innblikk i kva studentane meiner er vanskeleg med skrivearbeidet. Det er spesielt tre oppgåver i skrivearbeidet som peiker seg ut som utfordrande. Det er kjeldesøk og kjeldehandsaming, formulering av problemstilling og tekststruktur.

$75 \%$ av respondentane meiner det er vanskeleg å finne relevante kjelder, medan $69 \%$ meiner at riktig referering er vanskeleg. Heile $87 \%$ meiner at det er vanskeleg å formulere problemstilling, og 58\% meiner det er vanskeleg eller svært vanskeleg å strukturere tekst. Overraskande 59\% seier at det ikkje er vanskeleg å skrive på engelsk.

\begin{tabular}{|c|c|c|c|}
\hline & Not challenging & Somewhat challenging & Very challenging \\
\hline Finding relevant sources & $25 \%$ & $58 \%$ & $17 \%$ \\
\hline $\begin{array}{l}\text { Creating a thesis } \\
\text { statement }\end{array}$ & $13 \%$ & $61 \%$ & $26 \%$ \\
\hline Text structure & $42 \%$ & $45 \%$ & $13 \%$ \\
\hline Writing in English & $59 \%$ & $32 \%$ & $9 \%$ \\
\hline Finding amy own voice» & $48 \%$ & $40 \%$ & $12 \%$ \\
\hline $\begin{array}{l}\text { Correctly referencing } \\
\text { sources }\end{array}$ & $32 \%$ & $48 \%$ & $21 \%$ \\
\hline
\end{tabular}

Fig. 4. Tabell som viser kva studentane meiner er vanskeleg i skriveprosessen

Kva betyr desse funna? Kjeldekompetanse krevast i dei aller fleste skriveoppgåver ved universitet og høgskular i Noreg i dag. Det er ein generell kompetanse, og ofte blir undervisninga rundt kjeldebruk gitt av universitetsbiblioteka. Slik er det også ved UiA. Samtidig erfarer universitetsbiblioteka at generelle kurstilbod i kjeldehandsaming ikkje greier å tiltrekke seg ingeniørstudentane. Det er fyrst når slike kurs blir innlemma i programfaga og lagt til timeplanen at studentane møter.

Sjølve innhaldet i kurs om kjeldehandsaming kan ofte bli tekninsk, og studentane kan ytre frustrasjon over nitidig pirk på til dømes teiknsetjing i kjeldelista. Men også her kan undervisninga og rettleiinga tilførast Dysthe si dialogiske tilnærming. Denne tilnærminga til rettleiing rundt kjeldehandsaming handlar om å prøve å få nye studentar til å forstå at kjeldereferering ikkje berre er eit formelt krav, men at det er ein måte å vise at forfattaren har vore i dialog med, og henta idear frå, andre tekstar innanfor same fagområde. Dialogen er altså 
her intertekstuell (Dysthe, 1997). På den måten kan den akademiske skrivaren posisjonere seg innanfor eit fagområde.

Den andre utfordringa studentane har er å lage problemstilling. Dette er ei oppgåve som er sjangerspesifikk og også fagpesifikk. Å stille eit spørsmål eller ein hypotese, og så svare på den verkar vere ei ukjent oppgåve for mange fyrsteårsstudentar. Samtidig er problemformulering ein av kjerneelementa i den tekniske fagrapporten på ingeniørfag. Dette gjeld både enkle labrapportar og lengre avhandlingar, som til dømes bachelorrapporten.

For å greie å formulere gode spørsmål må ein ha noko kjennskap til fagområdet. Ein må vite litt om kva type spørsmål som er for openberre, og kva som er umogleg å svare på. Ein må også greie å svare innanfor rammene av oppgåva. Å formulere ei god problemstilling er såleis ein del av 'sosialiseringa' inn i fagdisiplinen (Rienecker \& Stray Jørgensen, 2018).

Fyrsteårsstudentar ser ut til å vere betre rusta til å skrive ekspressive og gjenforteljande tekstar enn kritiske og kunnskapsproduserande tekstar (Berge et al., 2005; Hertzberg et al., 2007). Det å skrive tekst som kunnskapsproduksjon er derfor ei meir eller mindre ukjend oppgåve for studentar i fyrste semester. Å forstå skilnaden mellom ein deskriptiv tekst og ein fagtekst innanfor eit fagområde (t.d ein teknisk rapport) krev kjennskap til konvensjonen og sjangeren den skrivast i. Nye studentar har ikkje denne kjennskapen. Dei held seg til det Rienecker (2019) kaller for 'den prekonvensjonelle' skrivinga. Den er prega av gjenforteljing, og tidvis plagiat, frå kjeldene, og manglar forfattaren si 'eiga stemme' (s. 26). Denne prekonvensjonelle, eller beskrivande måten å skrive på er ein vane som er vond å vende. Likevel er akkurat den vendinga nødvendig dersom studentar skal lære å skrive slik det er forventa av dei. Denne 'innsosialiseringa' (Rienecker, 2019; Zhu, 2004) i fagskriving krev tid og arbeid. Den krev meir enn språklege og faglege ferdigheiter. Det krev også meir enn forelesningar om korleis enn skal referere riktig, eller trugslar om plagiatbeskuldningar, for den del. Det er ein lang prosess og det krev fagleg modenheit. Fagmiljøa og skrivemiljøa må nok saman erkjenne at dersom studentane skal få vere i denne prosessen krev det kontinuitet og meir oppfølgjing $\mathrm{i}$ skriveopplæringa på ingeniørstudiet.

Den tredje utfordringa studentane har med skrivinga er å strukturere tekst. Tekstoppbygging er til ein viss grad ein generell kompetanse. Det er i alle fall noko studentane har jobba med frå tidleg skulegang, og er inkludert i 'dei fem grunnleggande ferdigheitene' (Utdanningsdirektoratet, 2020). Likevel verkar det ikkje som om denne kompetansen er overført til skriveoppgåvene som ventar ved studiestart. Ei forklaring kan vere at studenten mister synet for det ho tidlegare meistra (eller i alle fall delvis meistra) når ho $\mathrm{i}$ sin nye studiekvardag blir overvelda av formelle krav, nye malar, nye fagkunnskapar og nye sjangrar (Bernadier, 2019; Jonsmoen \& Greek, 2017). Ei anna forklaring kan vere at ingeniørstudentar generelt sett ikkje er så interessert i å skrive (Lievens, 2012; Shapiro, 1991).

I alle høve kan skriveopplæringa prøve å koble saman studentane sine skrivekunnskapar frå grunnskule og vidaregåande skule med dei nye skriveoppgåvene dei møter i studiet. På den måten kan dei vise at tidlegare skriveerfaring kan brukast i møtet med nye skrivesituasjonar, og 
dei fagspesifikke konvensjonane kan så koblast saman med ein generell 'retorisk bevisstheit' (Kim \& Olson, 2020) .

Så kva er vanskeleg for studentane i fyrste semester? Generelle kunnskapar om tekststruktur, tekstflyt og godt grammatisk språk verkar å drukne i forsøket på å innfri dei formelle krava studentane møter på ingeniørutdanninga. Det stillast krav om sjangerforståing, informasjonskompetanse og fagleg forståing. I tillegg kjem krav om godt formelt språk i tråd med disiplinen sine konvensjonar. Det er ikkje underleg at dette kan verke overveldande, og det er ikkje urimeleg at det krev tid og modenheit. Her er samarbeidet mellom fagmiljø, skrivelærar og bibliotek både nyttig og nødvendig. Det krev ein 'akademisk landsby' av skrivekyndige og fagleg kyndige som saman kan bidra til å løfte studentane sine skriveferdigheiter til det nivået som er forventa av dei i fagdisiplinen. Samtidig er det nyttig at skrivemiljø og fagmiljø samkøyrer forventningane til språkkompetanse i dei faglege tekstane.

\section{Kategori 4}

Funna i den fjerde gruppa skildrar studiekoordinatorane sine syn på skriving og skriveopplæring på ingeniørstudiet. Studiekoordinatorane er fagleg tilsette (ingeniørar) som utformar studieplanar, underviser og rettleier studentane i dei respektive fagmiljøa. Dei følgjer studentane sitt studieforløp gjennom heile bachelor- og masterutdanninga. Det er fem ulike studieretningar innan ingeniørstudia ved UiA: byggdesign, fornybar energi, data, elektronikk og mekatronikk. I skrivesamtalene fekk alle dei fem studiekoordinatorane svare ope på fire spørsmål:

1. Kva innhald meiner du bør inkluderast i eit skrivekurs for ingeniørstudentar?

2. Kva meiner du er studentane sine svakheiter ved fagskriving?

3. Korleis vektlegg du språkføring i vurdering og rettleiing av fagtekst på bachelornivå?

4. Korleis vektlegg du kjeldebruk i vurdering og rettleiing av fagtekst på bachelornivå?

Mange av svara frå studiekoordinatorane samsvarer med studentane sine svar i kategori 3 , spesielt når det gjeld informasjonskompetanse og formulering av problemstilling. Samtidig meiner studiekoordinatorane at språklege svakheiter kan hindre god kommunikasjon i fagtekstar.

Svara i spørsmål 1 og 2 er rimeleg samkøyrde. Studieprogramleiarane uttrykker at problemområda til studentane ofte er upresist språk, noko mangel på språklege ferdigheiter, mangelfull forståing for kjeldebruk og kjeldevurdering og problem med å strukturere tekst. Korrekt grammatisk språk blei framheva av tre av studiekoordinatorane. Ein av dei uttrykker seg slik:

Ellers kan det sikkert også være interessant å fremheve behovet for presist språk (...). Grammatikk og staving er også relevante områder. Det er heller ikke alle studenter som ser behovet for å ha et verb i en setning.

Alle studieprogramleiarane uttrykker frustrasjon over studentane sine manglande skriveferdigheiter. Samtidig ser dei på si eiga rolle som utilstrekkeleg når det gjeld rettleiing av språk og grammatikk. Dei etterspør derfor undervisning om dette. Dei etterspør også gode 
dømer på korleis ein kan formulere forskerspørsmål, og korleis ein skil mellom dei ulike delene av ein teknisk rapport (teori, funn, diskusjon...). Nokre studieprogramleiarar meiner at kjeldesøk og kjeldekritikk er svært viktige tema å dekke i skriveundervisninga: Det med plagiat bør tas opp. Forklare hva plagiat er og hva som ikke er plagiat når man gjengir ting fra en kilde.

Når studieprogramleiarane blei spurde om kor mykje språk og kjeldekompetanse skal telje i vurderinga av studentane sine tekstar var svara svært varierte. I eit av studieprogramma tel god språkføring med $10 \%$ av totalvurderinga av store oppgåver. I andre studieprogram finns ikkje slike føringar, og vurdering av språkferdigheter er opp til kvar enkelt undervisar (sensor). Det same gjeld spørsmål om kjeldebruk. Til og med samtaler om kva som reknast som plagiat viser at det er store skilnader innad i fagmiljøa.

Studiekoordinatorane stiller seg positive til bidraga frå skrivemiljøa. Ei haldning om at 'alle monner drar' blir uttrykt av samtlege studiekoordinatorar. Dersom ein skal lage gode skrivekurs må ein kjenne til dei fagspesifikke skrivetradisjonane, ha kjennskap til disiplinen og kva sjangrar og språkføring som er forventa i fagmiljøet (Hyland, 2002b). Derfor har samtalene med fagmiljøa vore svært nyttige for utforminga av skrivekursa på ingeniørutdanninga. Samtalene har også bidratt til meir kunnskap om korleis fagmiljøa saman med biblioteket kan utvikle skrivekurs som blir sett på som nyttige, både for studentane og dei fagleg tilsette. Dette kan igjen vere med på å redusere forvirring rundt kor mykje språkføring og kjeldekompetanse skal telje i vurderinga av t.d bachelorrapporten.

Samtalene om skriving og utarbeiding av kursinnhald har i så måte fungert som brubygging mellom fagmiljøa og skrivemiljøa ved universitetet.

\section{Konklusjon}

Målet med denne undersøkinga var å finne ut kva studentane meiner om skrivekurset som haldast ved fyrste semester på ingeniørutdanninga ved UiA og korleis kurset kan forbedrast. Eit anna mål var å bidra til diskursen om skrivekurs på den norske ingeniørutdanninga.

Denne studien har avgrensningar. Det er litt få respondentar og spørjeundersøkinga går ikkje inn på kva som kan gjere studentane til betre skribentar. Likevel kan dataen brukast til vidare arbeid med å utvikle skrivekurs på ingeniørutdanninga.

Studien bidrar til kunnskap på to områder. For det første treng studentane både element av det fagspesifikke og det generelle i skriveopplæringa. Skrivekurs opplevast som nyttige. Kunnskapen om, og ferdigheitene i skriving brukast i seinare skrivearbeid. Utfordringane studentane har med skrivearbeidet er ikkje nødvendigvis knytta til det disiplinære, men heller til dei samla utfordringane skrivinga gir: struktur, problemstilling og kjeldehandsaming, men også sjanger og språkføring som forventast i fagmiljøet. Å lære seg å skrive etter ingeniørfaglege konvensjonar er ein prosess som tek tid. Skrivetilboda må ta høgde for dette og prøve å halde ein viss kontinuitet i skriveopplæringa fordelt utover studieforløpet. God 
skriveopplæring krev meir enn nokre tilfeldige skrivekurs. For det andre visers samarbeidet mellom bibliotek, skrivelærar og ingeniørfagleg tilsette seg å være nyttig både for å velje innhald i skrivekurs, men også for å knytte ingeniørfagleg miljø og skrivemiljø sterkare saman. Den brubygginga har ikkje berre effekt på utforminga av skrivekursa, men også på korleis skrivetilboda oppfattast i dei ingeniørfaglege miljøa. Skrivesamtalene med ingeniørfagleg tilsette fører også til auka bevisstgjering på skriving og språk i fagdisiplinane. Ei kompetanseutveksling foregår såleis mellom ingeniørfagleg miljø og skrivemiljø.

For å utvikle skrivekursa til å bli betre er det nødvendig å jobbe vidare på dette området. Det trengst meir kunnskap om og ei større bevisstheit rundt kva som gjer skriveundervisninga god, og korleis den bør utførast ved ingeniørutdanninga. Då er det nødvendig med ein breiare analyse av studentane og dei ingeniørfagleg tilsette sine oppfatningar om skriveopplæringa, ikkje berre frå ein studiestad, men frå fleire. Ingeniørutdanningane i Noreg hadde vore tent med eit samla forum for å diskutere kva skriveundervisninga på ingeniørfag skal innehalde og korleis den bør gjennomførast. Som tidlegare nemnt, det krev 'ein landsby'.

\section{Referanser}

Andersen, A., Fagerlid, C., Larsen, H. \& Straume, I. (Eds.). 2017. Det åpne bibliotek. Forskningsbibliotek $i$ endring. Oslo: Cappelen Damm Akademisk. DOI: $10.23865 /$ noasp. 20

Bartholomae, D. (1995). Writing with Teachers: A Conversation with Peter Elbow. College Composition and Communication, 46(1), 62-71. National Council of Teachers of English. Retrieved from https://www.jstor.org/stable/358870

Bazerman, C., Little, J., Bethel, L., Chavkin, T., Fouquette, D. \& Garufis, J. (2005). Reference Guide to Writing Across the Curriculum. West Lafayette, IN: The WAC Clearinghouse.

Berge, K. L., Evensen, L.S., Vagle, W. \& Hertzberg, F. (2005). Ungdommers skrivekompetanse. Norsksensuren som kvalitetsvurdering (bind 2, s 387 - 393).

Bernadier, C. (2019). Genre maps as a method to visualize engineering writing and argumentation patterns. Journal of Engineering Education, 108, 377-393 DOI: $10.1002 /$ jee.20281

Busch, T. (2018). Akademisk skriving: For bachelor - og masterstudenter. Bergen: Fagbokforlaget.

Dawson, P., Henderson, M., Mahoney, P., Phillips, M., Ryan, T., Boud, D. \& Molloy, E. (2018). What makes for effective feedback: staff and student perspectives, Assessment and Evaluation in Higher Education, 44:1, 25-36. DOI:

10.1080/02602938.2018.1467877

Dysthe, O. (red). (2001). Dialog, samspel og loering. Oslo: Abstrakt forlag.

Dysthe, O. (1997). Skriving sett i lys av dialogisme. Teoretisk bakgrunn og konsekvensar for undervisning. In Evensen, L. \& Hoel, T.L. (Eds.), Skriveteorier og skolepraksis (s. 4578). Oslo: Cappelen akademisk forlag. 
Dysthe, O., Hertzberg, F. \& Hoel, T.L. (2010). Skrive for å laere -skriving i høyere utdanning 2nd ed. Oslo: Abstrakt forlag.

Eik-Nes, N. (2007), Akademisk skriving: En dialog mellom sjanger og prosess. In Matre, N \& Hoel, T.L: (Eds.), Skrive for nåtid og framtid: Skriving og rettleiing i høgre utdanning (s. 138-149). Trondheim: Tapir akademisk forlag.

Folkvord, I. \& Thowsen, I. (2007). Med fagteksten i fokus: Dynamisk normering av skrivearbeidet fram mot masteroppgaven. In Matre, N \& Hoel, T.L. (Eds.), Skrive for nåtid og framtid: Skriving og rettleiing i høgre utdanning (s. 175-187). Trondheim: Tapir akademisk forlag.

Gassman, S., Maher, M. \& Timmerman, B., (2013) Supporting Students’ Disciplinary Writing in Engineering Education, International Journal of Engineering Education 29(5), 1270-1280.

Hertzberg, F. \& Roe, A. (2016). Writing in the content areas: A Norwegian case study, Read Writ, (2016) 29, 555-576. DOI: 10.1007/s11145-015-9607-7.

Howard, S., Khosronejad, M. \& Calvo, R. (2017). Exploring Engineering instructors' views about writing and online tools to support communication in Engineering. European Journal of Engineering Education, 42(6), 875-889. DOI: 10.1080/03043797.2016.1228612

Hyland, K. (2002a). Teaching and researching writing (2nd ed). Pearson.

Hyland, K. (2002b). Specificity revisited: how far should we go now? English for Specific Purposes, 21, 385-395 PII: S0889-4906(01)00028-X

Hyland, K. (2007) Genre pedagogy: Language, literacy and L2 writing instruction, Journal of Second Language Writing 16 (2007)148-164.

Jonsmoen, K. M. \& Greek, M. (2012). Skrivekår i profesjonsutdanning. Uniped, 35(4), 4-13. DOI:10.3402/uniped.v35i4.20258

Jonsmoen, K. M. \& Greek, M. (2017). "HODET BLIR TUNGT - OG TOMT” - om det å skrive seg til profesjonsutøvelse. Norsk pedagogisk tidsskrift 1, 15-26.

Jordan, J. \& Kedrowicz, A. (2011). Attitudes about graduate L2 writing in engineering: Possibilities for more integrated instruction. Across the Disciplines, 8(4). Retrieved from https://wac.colostate.edu/docs/atd/ell/jordan-kedrowicz.cfm

Kim, D. \& Olson, W. (2020). Using a Transfer-Focuses Writing Pedagogy to Improve Undergraduates' Lab Report Writingin Gateway Engineering Laboratory Courses. IEEE Transactions on Professional Communication, 63(1), 64-83. DOI: IEEE 10.1109/TPC.2019.2961009

Lievens, J. (2012). Debunking the 'Nerd' Myth: Doing Action Research with First-year Engineering Students in the Academic Writing Class. Journal of Academic Writing, 74-84. 10.18552.

Lovdata. (2018). Forskrift om rammeplan for ingeniørutdanning 2019. Retrieved from https://lovdata.no/dokument/LTI/forskrift/2018-05-18-870

Peterson, L. (2012). WAC and Freshman Writing. Anticipating the difficulties, Avoiding the Pitfalls. 48 - 49.

Pitt, E. \& Norton, L. (2016). Now that's the feedback I want! Students' reactions to feedback on graded work and what they do with it. Assessment and Evaluation in Higher Education, 42(4), 499-516, DOI: 10.1080/02602938.2016.1142500. 
Rienecker, L. \& Stray-Jørgensen, P. (2018). The Good Paper: A Handbook for Writing Papers in Higher Education (2. ed.). København: Samfundslitteratur.

Rienecker, L., Wichmann-Hansen, G. \& Stray-Jørgensen, P. (2019). God vejledning af specialer, bacheloroppgaver og projekter (2. ed.). København: Samfundslitteratur.

Shapiro, A. (1991). WAC and Engineering, or Why Engineers Can't Write.

Smidt, J. (Ed.). (2010). Skriving i alle fag - innsyn og utspill. Trondheim: Tapir akademisk forlag.

Strand, H. (2007). Vagval for den akademiska skrivundervisningen. In Matre, N \& Hoel, T.L. (Eds.). Skrive for nåtid og framtid: Skriving og rettleiing $i$ høgre utdanning. Trondheim: Tapir akademisk forlag.

Universitets- og høyskolerådet. (2011). Nasjonale retningslinjer for ingeniørutdanning - på vei mot fremtiden. Retrived from https://www.regjeringen.no/globalassets/upload/kd/rundskriv/2011/nasjonale_retnings linjer_ingenioerutdanning.pdf

Utdannings- og forskningsdepartementet. (2006). Kunnskapsløftet. Kultur for loering. Publikasjonskode: F-4189 B. Retrieved from https://www.regjeringen.no/globalassets/upload/kilde/ufd/prm/2005/0081/ddd/pdfv/25 6458-kunnskap_bokmaal_low.pdf

Våga, A.B., Hårklau, A. \& Vik-Haugen, L. (2017). Akademisk skriveveiledning i UHinstitusjonene. Universitets- og høgskolerådet. Retrieved from https://www.uhr.no/_f/p1/i4cf4bb3d-e3d9-47c0-bc10-44141b8b5d43/rapportakademiskskriveopplaring.pdf

$\mathrm{Zhu}, \mathrm{W}$. (2004). Faculty views on the importance of writing, the nature of academic writing, and teaching and responding to writing in the disciplines. Journal of Second Language Writing, 13. 29-48. 